\title{
Haemophilus influenzae porine ompP2 gene transfer mediated by graphene oxide nanoparticles with effects on transformation process and virulence bacterial capacity
}

\author{
Julia Nogueira Varela', Maria Cecília Krähenbühl Amstalden', Rafaella Fabiana Carneiro Pereira', \\ Luciana Maria de Hollanda ${ }^{1}$, Helder José Ceragioli², Vitor Baranauskas ${ }^{2}$ and Marcelo Lancellotti ${ }^{*}$
}

\begin{abstract}
Background: $H$. influenzae is a natural competent bacterium that can uptake DNA from the environment and recombine into bacterial genome. The outbreaks of Brazilian purpuric fever, heavily polluted areas of a different H. influenzae biogroup - aegyptius - as well as gene transference between Neisseria meningitis make the transformation process an important evolutionary factor. This work studied the horizontal transference of the ompP2 gene from a multiresistant strain of $\mathrm{H}$. influenzae 07 (NTHi), under the influence of graphene oxide nanoparticles in order to mimic an atmosphere rich in suspended particles and this way verify if the CFU transformants number was increased.

Material and methods: In this article the gene ompP2 was transformed into different strains of $H$. influenzae mediated or not by graphene oxide nanoparticles in suspension, followed by the adhesion tests in Hec-1B (human endometrium adenocarcinoma) and A549 (pulmonary epithelial carcinoma) cells lines. The transformation frequency and the adhesion capacity were determined in all the mutants to which the ompP2 gene was transferred and compared to their wild type strains.
\end{abstract}

Results: The nanoparticles increased the transformation ratio of one particular strain isolated from a pneumonia case. The adhesion patterns to A549 and Heclb cell lines of these mutated bacteria has their capacity increased when compared to the wild type.

Conclusions: Graphene oxide nanoparticles aid the transformation process, helping to increase the number of CFUs, and the mutants generated with the ompP2 gene from a $\mathrm{H}$. influenzae resistant strain not only present a chloramphenicol resistance but also have an increased adherence patterns in A549 and Hec1B cell lines.

Keywords: Haemophilus influenzae, Graphene oxide, Bacterial transformation, Outer membrane protein, Virulence, Porin

\section{Background}

Haemophilus influenzae is a gram-negative pleomorphic cocobacillus that usually colonizes the upper respiratory tract in humans. This specie can be classified by two methods: biotypes and serotypes. The division into biotypes is based on the presence and production of enzymes such as ornithine descarboxylase, urease and those that act

\footnotetext{
* Correspondence: mlancell@unicamp.br

'LABIOTEC - Biotechnology Laboratory, Department of Biochemistry, Institute of Biology CP6109, University of Campinas - UNICAMP 13083-970, Campinas, São Paulo, Brazil

Full list of author information is available at the end of the article
}

on fermentation of D-xylose and on the production of indol. With this classification, Haemophilus influenzae can be divided into 9 biotypes: I to VIII and aegyptius [1,2]. $H$. influenzae can also be classified based on the production of a polyssacharide capsule composed by a 3 - $\beta$-ribose(1-1)-ribitol-phosphate polymer (RPR), whose antigenic structure divides the capsulated strains into 6 immunologic known serotypes: a - f [3] and non-typed strains, which do not produce capsule [4]. Other methods such as membrane protein analysis, lipopolysaccharide profile and isoenzymes electrophoresis can be used for the

\section{() BioMed Central}

(c) 2014 Varela et al.; licensee BioMed Central Ltd. This is an Open Access article distributed under the terms of the Creative Commons Attribution License (http://creativecommons.org/licenses/by/2.0), which permits unrestricted use, distribution, and reproduction in any medium, provided the original work is properly credited. The Creative Commons Public Domain Dedication waiver (http://creativecommons.org/publicdomain/zero/1.0/) applies to the data made available in this article, unless otherwise stated. 
purpose of studying and understanding the epidemiology of $H$. influenzae [5].

$H$. influenzae type $\mathrm{b}$ is the most invasive of all serotypes and known as the main causer of meningitis, as well as the most relevant pathogen of the upper respiratory tract in children and in adults [6-9]. H. influenzae is responsible for 30 to $50 \%$ of all bacterial meningitis over the world and the second most common agent of pneumonia in children [10]. The non-typed forms of $H$. influenzae (NTHi) are generally associated to moderate diseases of the upper respiratory tract in children and pneumonia in adults with Chronic Obstructive Pulmonary Disease (COPD) or Cystic Fibrosis [11]. The polyssaccharidic capsule is considered the main antigen of this microorganism [3]. Another important pathogen factor is the lipopolyssacharides (LPS) associated with outer membrane proteins (OMP), which causes high fever and coagulation disorders [12].

H. influenzae resistance to antibiotics increased significantly over the last 20 years. This resistance is worse to beta-lactamic drugs, due to their production of betalactamase [13]. Since the first reports of $H$. influenzae resistant strains to ampicillin in 1974 in the USA, the main proposed mechanism was the production of betalactamases TEM-1 and ROB-1 by plasmids. The prevalence of beta-lactamase producing strains increased 15, 2\% from 1983 to 1984 and 31, 3\% from 1997 to 1998 . $H$. influenzae is not only resistant to ampicillin; they also present non-susceptibility to cephalosporin, trimethoprim, cephalosporin, tetracycline and sulfonamides [14-17].

One of the main reasons for the emergence of multiresistant strains over the last years is the horizontal gene transfer. $H$. influenzae is considered to be natural competent, i.e., a bacterium capable of taking up exogenous DNA and incorporating it into its own genetic material by transformation $[18,19]$. These new genes incorporated onto the genetic code may provide mechanisms to avoid or inhibit the action of antimicrobial drugs. Even small amino acid changes in proteins can enhance the resistance of bacteria to drugs. One example is the Outer Membrane Proteins (OMP) also known as porines, which in H. influenzae are classified from P1 to P6, in order of their decreasing molecular weight (Figure 1) [20]. Small changes on the amino acid sequence of one of these proteins were related to an increase of antibiotics resistance in Haemophilus influenzae strains isolated from cystic fibrosis patients [21]. Porines isolated from resistant strains present a lower electric conductibility than wild-type porines. This would explain the non-susceptibility to beta-lactamic antibiotics and other drugs with low molecular weight [22].

The use of organic and inorganic nanomaterials is nowadays a new promising tool to biomedical researches, as for example in cancer treatment and diagnostics, drug delivery systems and bacterial processes [23]. Researches
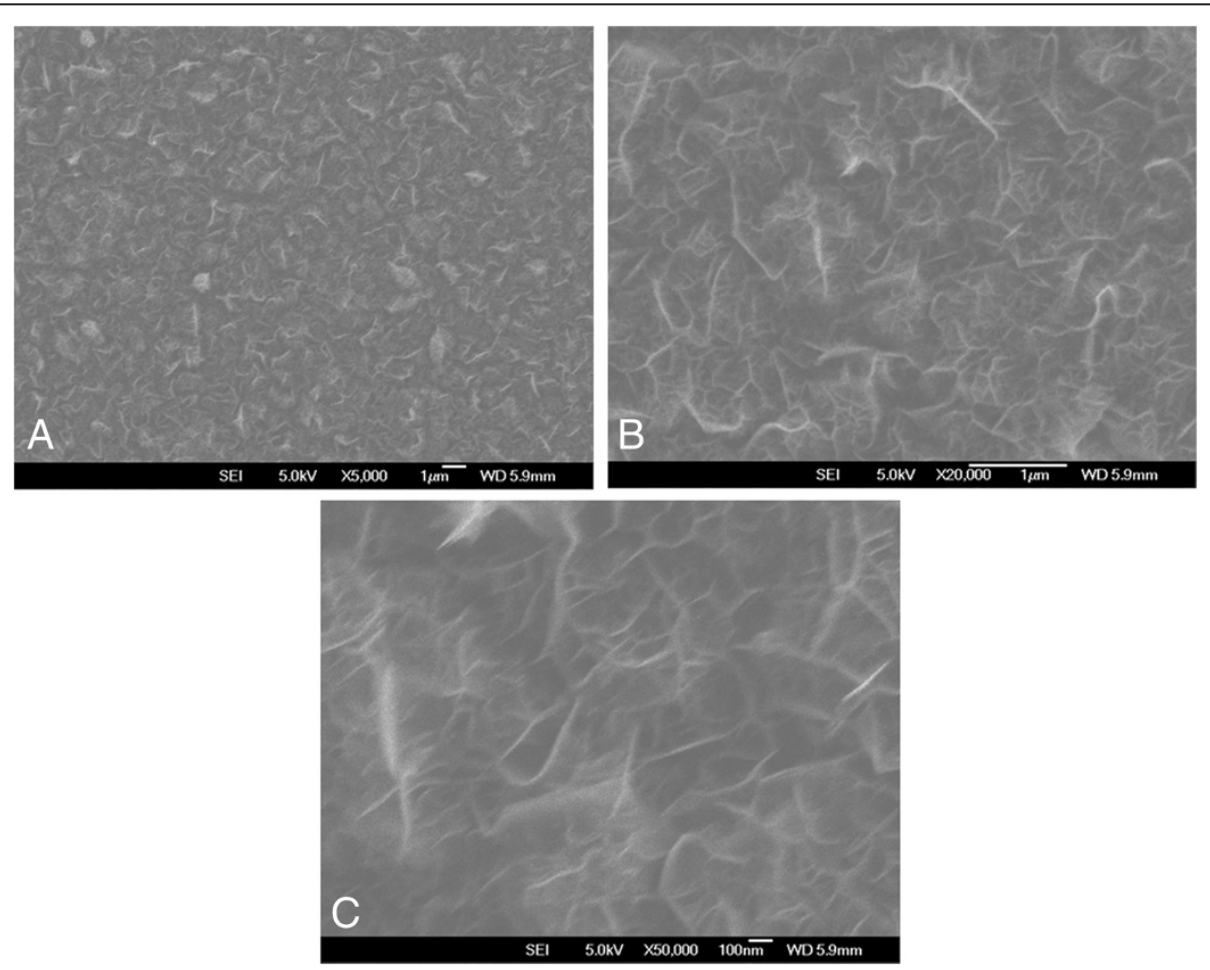

Figure 1 Field emission electron microscopy show in different size and magnification of graphene oxide (in A: panoramic view, B: micrometric scale and C: nanometric scale). 
have shown that transformation frequencies and transformation process can be influenced by nanoparticles, especially mesoporous silica and carbon nanotubes [24-26]. Graphene oxide nanoparticles (GON), a layered structure of oxidized graphene sheets with epoxy- and hydroxyl groups at their edges, is a new material that attracts attention due to their distinct electronic, thermal and mechanical properties $[27,28]$. However, their potential role on bacterial transformation is still unknown. As graphene is composed by carbon atoms, it shows similar chemical characteristics to nanoparticles present in the atmosphere of highly polluted regions, provoking respiratory disorders when these particles are inhaled.

This work aimed to see the effect of grapheme oxide nanoparticles on the transformation frequency of $H$. influen$z a e$; especially on the horizontal transfer of omp $\mathrm{P} 2$ amplicon obtained from NTHi serotype 07, resistant to chloramphenicol and tetracycline; as well as to verify the adhesion of mutant and wild-type strains on cells A549 and Hec-1-B in the presence of antibiotics.

\section{Methods}

\section{Bacterial strains}

All strains used in this work are listed in Table 1. H. influenzae strains were grown in chocolate agar or BHI agar (Difco) supplemented with NAD (Sigma, Saint Louis, MO, USA) $0,2 \mathrm{mg} / \mathrm{ml}$ and hemin (Sigma, Saint Louis, MO, USA) $2 \mathrm{mg} / \mathrm{ml}$ at $37^{\circ} \mathrm{C}$ with $5 \% \mathrm{CO}_{2}$ for $18-24$ hours.

\section{Cell cultures}

Cell lines A549 (pulmonary epithelial carcinoma) and Hec1-B (human endometrium adenocarcinoma) were obtained at the Institute Adolfo Lutz, Brazil. They were cultivated at RPMI medium 1640 (Cultilab, Campinas, Brazil) with 1020\% Bovine Fetal Serum (BFS), depending the cellular lineage, and maintained at $37^{\circ} \mathrm{C}$ with $5 \% \mathrm{CO}_{2}$. After the semiconfluent cell layer formation, the cells were trypsinized and transferred to a 24-well polystyrene plate. Each well received $1 \mathrm{ml}$ of cell culture and the cell concentration after its trypsinization was 1.106 cells $/ \mathrm{ml}$. Cells were incubated under same conditions as previously described.

\section{Graphene oxide nanoparticles synthesis}

Graphene oxide nanoparticles were prepared after a catalytic conversion using a cupper substratum. $1 \mathrm{ml}$ of a polyaniline diluted in dimethylformamide was added on the substratum and dried in room temperature for two hours. On the substratum with polyaniline was put $0,2 \mathrm{ml}$ of a solution of nickel nitrate diluted in acetone. Cupper substratum was immersed into a chemical vapor deposition reactor assisted by a hot filament. The reactor contained a carbon source formed by camphor, acetone and citric acid. Raman spectrometry and Field Emission Scanning Electron Microscopy can be seen in Figure 2.

\section{ompP2 gene amplification}

Genomic DNA from $H$. influenzae strain NTHi 07 was extracted using the protocol described by Sambrook et al. [29]. The sequence of the gene ompP2 was obtained at Genbank GI:2981106 (http://www.ncbi.nlm.nih.gov/ nucleotide). Primers used to gene amplification are listed in Table 2.

\section{Transformation process}

Grown bacteria were transferred to BHI broth supplemented with NAD $2 \mu \mathrm{g} / \mathrm{ml}$ and hemin $10 \mu \mathrm{g} / \mathrm{ml}$ at a final concentration of $\mathrm{D}_{600} 1,0$. Transformation process was made using $100 \mu \mathrm{l}$ of bacterial solution incubated with $5 \mu \mathrm{l}$ of $\operatorname{omp} \mathrm{P} 2$ amplicon at a concentration of $1 \mu \mathrm{g} / \mathrm{ml}$, followed by the addition of $15 \mu \mathrm{l}$ of graphene oxide nanoparticles at a concentration of $20 \mu \mathrm{g} / \mathrm{ml}$ for 30 minutes. Afterwards, $1 \mathrm{ml}$ of supplemented BHI broth was added

Table 1 Bacterial strains used in this work

\begin{tabular}{|c|c|c|}
\hline Strains & Characteristics & Origin \\
\hline Rd & Haemophilus influenzae standard strain completely sequenced, from sorotype d & INCQS - FIOCRUZ \\
\hline Hib-ßlac & Haemophilus influenzae serotype b ATCC & INCQS - FIOCRUZ \\
\hline $\mathrm{HiO7}$ & Haemophilus influenzae NTHi - CmR, TcR, ApR & LABIOTEC \\
\hline Hi38 & Haemophilus influenzae serotype a isolated from a pneumonia case & LABIOTEC \\
\hline Hi13 & Haemophilus influenzae NTHi hmw+ & LABIOTEC \\
\hline $\mathrm{Hi} 45$ & Haemophilus influenzae serotype b isolated from an hemoculture & LABIOTEC \\
\hline $\mathrm{Hi46}$ & Haemophilus influenzae serotype b isolated from a hemoculture & LABIOTEC \\
\hline $\mathrm{Hi} 47$ & Haemophilus influenzae NTHi isolated from a hemoculture & LABIOTEC \\
\hline Hic & Haemophilus influenzae serotype c ATCC 9007 NCTC 8469. & $\mid A L-S P$ \\
\hline Hie & Haemophilus influenzae serotype e NCTC 10479. & $\mid A L-S P$ \\
\hline Hif & Haemophilus influenzae serotype f NCTC 7918. & $\mid A L-S P$ \\
\hline
\end{tabular}

IAL - Adolfo Lutz Institute SP, INCQS - FIOCRUZ - National Institute of Quality Contol - Oswaldo Cruz Foundation. LABIOTEC - Biotechnology Laboratory - IB - UNICAMP. 


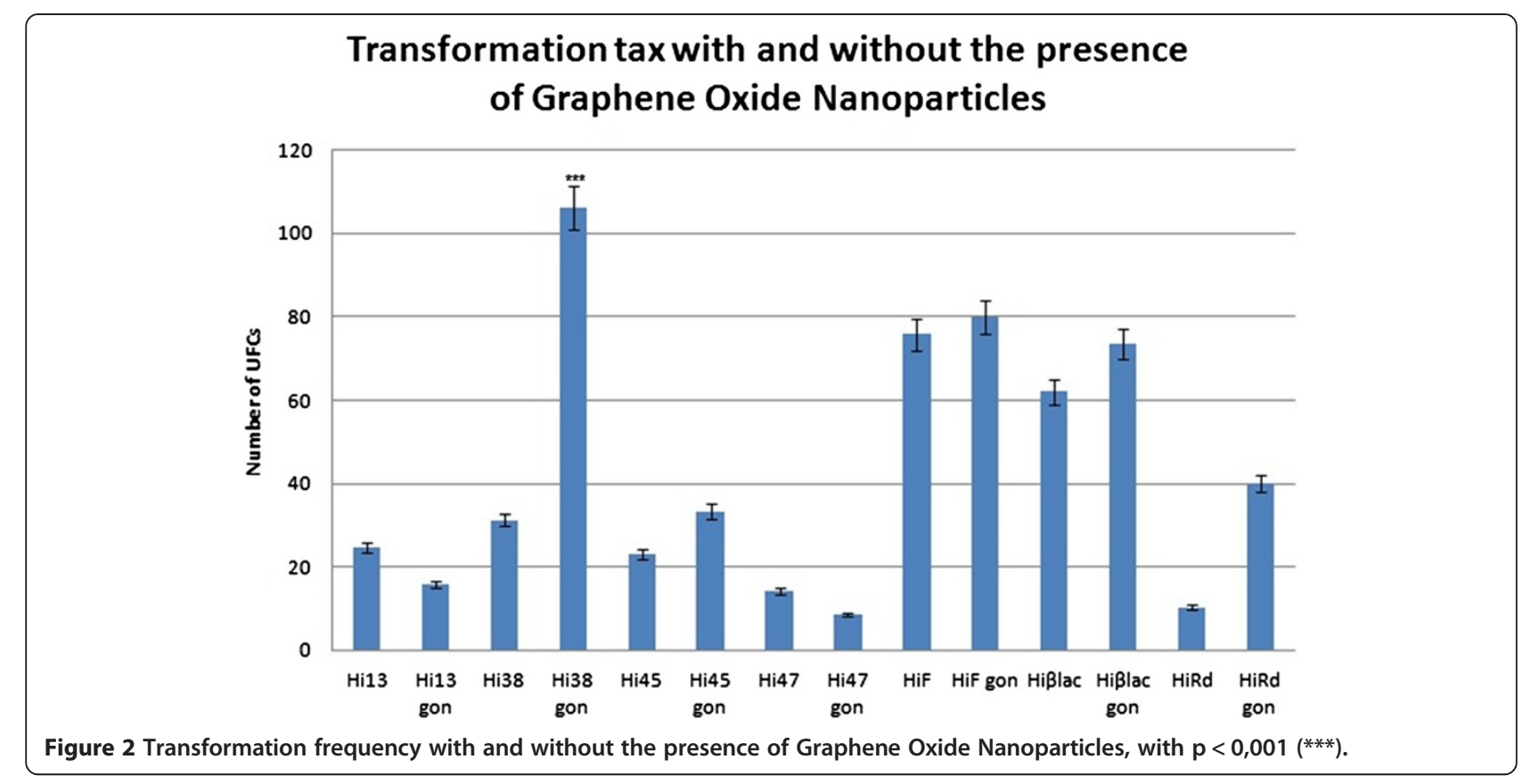

and the transformation was incubated at $37^{\circ} \mathrm{C}$ with $5 \%$ $\mathrm{CO}_{2}$ for 3 hours. An aliquot of $100 \mu \mathrm{l}$ was then transferred to BHI agar plate containing $2 \mu \mathrm{g} / \mathrm{ml}$ of chloramphenicol and incubated for 18 hours under the same described conditions. Negative control was made without the use of nanoparticles. Transformed CFU were count and statistical analysis was made by comparing the number of transformants obtained with and without the use of nanoparticles. To verify the successful gene acquisition, a PCR was made under the same conditions as previously described.

\section{Cytotoxicity assay}

Cytotoxicity tests were made to analyze whether the antibiotic present in bacterial medium would interfere on cellular growth. After 24 hours of incubation, the medium was removed, the wells were washed $3 \times$ with $0.1 \mathrm{~mL}$ of PBS Buffer (137 mM NaCl, $10 \mathrm{mM}$ phosphate, $\mathrm{KCl} 2.7 \mathrm{mM}$, and a $\mathrm{pH}$ of 7.4). 0.2 mL of RPMI1640 was added in each well. An initial concentration of chloramphenicol of $4 \mu \mathrm{g} / \mathrm{ml}$ was added into the first wells and diluted into half concentration in each well. After incubation for $3 \mathrm{~h}$ at $37^{\circ} \mathrm{C}$, the medium with dye was removed and carefully $0.2 \mathrm{~mL}$ of ethanol was added to solubilize the blue formazan (yielded from MTT reduction by viable cells). The plates were shaken for 10 minutes and the absorbance for each well was read in a spectrophotometer ELx800 Absorbance Microplate Reader (BioTek, USA) at $\lambda=570 \mathrm{~nm}$. The values were expressed as percentages of MTT reduction compared to the control, where cells were not exposed to test agents [30].

\section{Neutral red (NR) uptake assay}

The Neutral Red uptake assay was performed as described [31]. After incubation, the medium containing the dye was removed and the wells were rapidly washed with $0.2 \mathrm{ml}$ of calcium-formaldehyde solution $(10 \mathrm{ml}$ of $40 \%$ formaldehyde, $10 \mathrm{ml}$ of $\mathrm{CaCl}_{2} ; 10 \mathrm{ml}$ deionized water). The solution was discarded and $0.2 \mathrm{~mL}$ of ethanol-acetic acid was added ( $1 \mathrm{ml}$ of glacial acetic acid, $100 \mathrm{ml}$ of ethanol 50\%). The plate was kept for 15 minutes at room temperature and the absorbance for each well was read in a spectrophotometer ELx800 Absorbance Microplate Reader (BioTek, USA) at $\lambda=540 \mathrm{~nm}$ [32]. The values were expressed as percentages of NR uptake compared to the control, in which the cells were not exposed to test agents.

\section{Adhesion assay}

Adhesion assay on cells was performed based on the description of Scaletsky et al. [33]. $50 \mu \mathrm{l}$ of bacterial suspension with a concentration of $1.106 \mathrm{CFU} / \mathrm{ml}$ was added into each well containing $1 \mathrm{ml}$ of RPMI 1640 with $10 \%$ BFS and $2 \mu \mathrm{g} / \mathrm{mL}$ of chloramphenicol. After an incubation period of 3 hours at $37^{\circ} \mathrm{C}$ with $5 \% \mathrm{CO}_{2}$, cellular medium was removed and each well was washed five times with RPMI 1640, to remove bacteria that did not adhere to the cells. $1 \mathrm{ml}$ of RPMI was added to each

Table 2 Primers used

\begin{tabular}{lll}
\hline Primer & Nucleotids sequence 5'- 3' & Description \\
\hline PorHi Fw & ATTAATCGTTGGTGCATTCG & porHi forward \\
Por Hi Rev & GAAGTAAACGCGTAAACCTACAC & porHi reverse \\
\hline
\end{tabular}


well and its bottom was scraped with a micropipette tip to release adhered bacteria. An aliquot of $50 \mu \mathrm{l}$ was taken and plated into chocolate agar medium with chloramphenicol for the mutant strain and without the antibiotic for wild-type strains. The plates were incubated for 18 hours at $37^{\circ} \mathrm{C}$ with $5 \% \mathrm{CO}_{2}$ and $\mathrm{CFU}$ were counted.

\section{Statistical analysis}

Statistical analysis was performed using GraphPad Instat program: transformation efficiency was analyzed by Bonferroni test with the number of CFU transformants with and without the presence of graphene oxide nanoparticles. Considered values were $\mathrm{p}<0.05$. The adhesion assay was analyzed by Tukey's test with a comparison of a control sample. All experiments were made in triplicate.

\section{Results and discussion}

\section{Transformation process and resulting frequencies}

The graphic of transformation frequencies with and without the use of nanoparticles for each $H$. influenzae strain is shown in Figure 3. As we can see, the transformation frequencies vary among the strains. Hi38, Hi45, HiF, Hißlac and HiRd presented an increased transformation frequency with the presence of GON, whereas for the strains Hil3 and Hi47 these values were decreased. However, the only strain that presented an extremely significant value of $\mathrm{p}<0.001$ is $H$. influenzae 38 , as shown in Table 3.

The verification of omp P2 incorporation into the genomic DNA of the receptor strains was made by PCR analysis (data not shown). Studies of how nanoparticles effect transformation processes have already been made, proving to have an increase on its frequency. One hypothetical mechanism for this phenomenon could be explained by a complexation of the nanomaterial with DNA, avoiding its degradation by DNAse enzymes. The uptake of DNA and its incorporation into bacterial genetic material could be facilitated by these nanoparticles $[24,25]$.
GON are found in high concentration in polluted atmospheres, especially in arid regions. This way, the study of their influence on $H$. influenzae transformation mimics a natural environment of carbon nanoparticles in the atmosphere, helping the transformation process in bacteria that asymptomatically colonizes the upper respiratory tract in humans. In certain regions were primitive agriculture is practiced, performed by sugar cane burning, the resulting emission of micro and nanoparticles generate a major series of respiratory complications and infections [34]. This way, the only strain which presented a statistically significant increase of transformation frequency is $H$. influenzae 38. Interestingly, this strain distinguishes itself from the other studied strains by being clinically isolated from a pneumonia sample (Table 1); because of that, this bacterium can be more adapted to a carbon nanoparticle-concentrated atmosphere and therefore $\mathrm{m}$ use them in its own favor than strains isolated from blood cultures. As graphene oxide nanoparticles present a similar structure and physical-chemical characteristics than multiwalled carbon nanotubes and mesoporous silica nanoparticles, it is believed that these nanostructures share the same action mechanisms in transformation processes. Therefore, the same hypothesis previously presented can be applied to explain the major increase of transformation frequency of $H$. influenzae strain 38 with the presence of graphene oxide nanoparticles.

\section{Cytotoxicity}

Graphics of cellular viability under the effects of chloramphenicol results are shown in Figure 4. The highest concentration $(4 \mu \mathrm{g} / \mathrm{ml})$ led to a decrease of $20 \%$ for Hec-1-b and A549. For the concentration of $2 \mu \mathrm{g} / \mathrm{ml}$ used in the adhesion assay, the cell viability resulted in $83 \%$, thus chloramphenicol is not considered toxic under these conditions.

\section{Adhesion assay}

The graphics of cellular adhesion for wild-type and mutant strains in A549 and Hec1B cells with and without
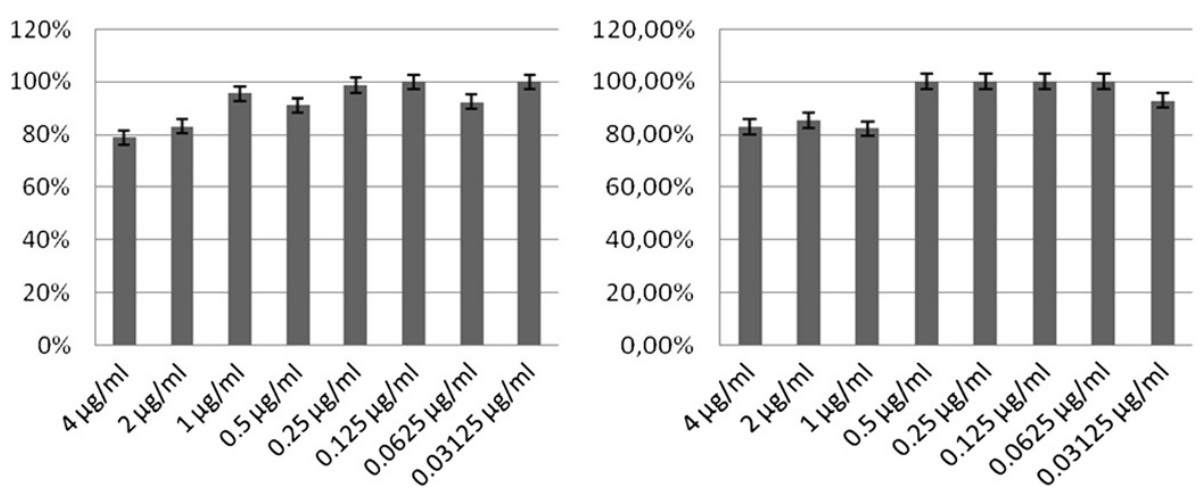

Figure 3 Citotoxicity in A549 and Hec1B cell lines. 
Table 3 Transformation tax value per colony forming unit and standard deviation

\begin{tabular}{ccc}
\hline Strains & CFU & STD \\
\hline Hi13 & 24.667 & 3.786 \\
Hi13 gon & 16 & 5 \\
Hi38 & 31.333 & 7.234 \\
Hi38 gon & 106 & 14.177 \\
Hi45 & 23 & 7.937 \\
Hi45 gon & 33.33 & 3.215 \\
Hi47 & 14.33 & 1.528 \\
Hi47 gon & 8.667 & 3.215 \\
HiF & 75.667 & 16.258 \\
HiF gon & 80 & 12.49 \\
Hißlac & 62 & 18.52 \\
Hißlac gon & 73.33 & 22.301 \\
HiRd & 10.33 & 4.041 \\
HiRd gon & 40 & 26.889 \\
\hline
\end{tabular}

the presence of chloramphenicol can be seen in Figure 5 . Wild-type strains of $H$. influenzae did not present any statistical relevant values for adhesion in A549 cells with or without the presence of antibiotics, while mutant strains $C$ and Blac show an increase of adhesion when chloramphenicol was added, resulting into a significant $\rho$ value of $\mathrm{p}<0.05$. By comparing wild-type and mutant strains, the adhesion of the first ones with and without chloramphenicol in A549 cells had an increase of $\mathrm{p}<$ 0.05 and $\mathrm{p}<0.001$, respectively.

As for the adhesion results in Hec1B cells, mutant strain Hi13M showed an increase of its adhesion in the presence of antibiotics when compared to the adhesion with its absence, with $\mathrm{p}<0.05$. In an environment without chloramphenicol, Hi46M also had an increase with a significant value of $\mathrm{p}<0.05$ compared to its wild-type strain. The comparison between wild-type and mutant strains with antibiotics presence revealed a clear increase of adhesion by the mutant strains. $H$. influenzae $13,47, \mathrm{C}$ and Blac mutant and wild-type strains presented an extremely significant $\mathrm{p}$ value of $<0.001$, while 46 strain had a very significant value of $\mathrm{p}<0.01$.

The adhesion assay to see the influence of mutation of omp $\mathrm{P} 2$ gene was proposed due to the importance of bacterial adherence at the mucosal surface on host organisms as a virulence factor [33]. The pulmonary adenocarcinoma cell lineage A549 was chosen due to $H$. influenzae predilection of respiratory tract [31], while Hec1B cells of endometrial adenocarcinoma were used with the purpose of mimetizing an endothelium [35]. As cytotoxicity results presented a cellular viability of over $80 \%$ at the highest

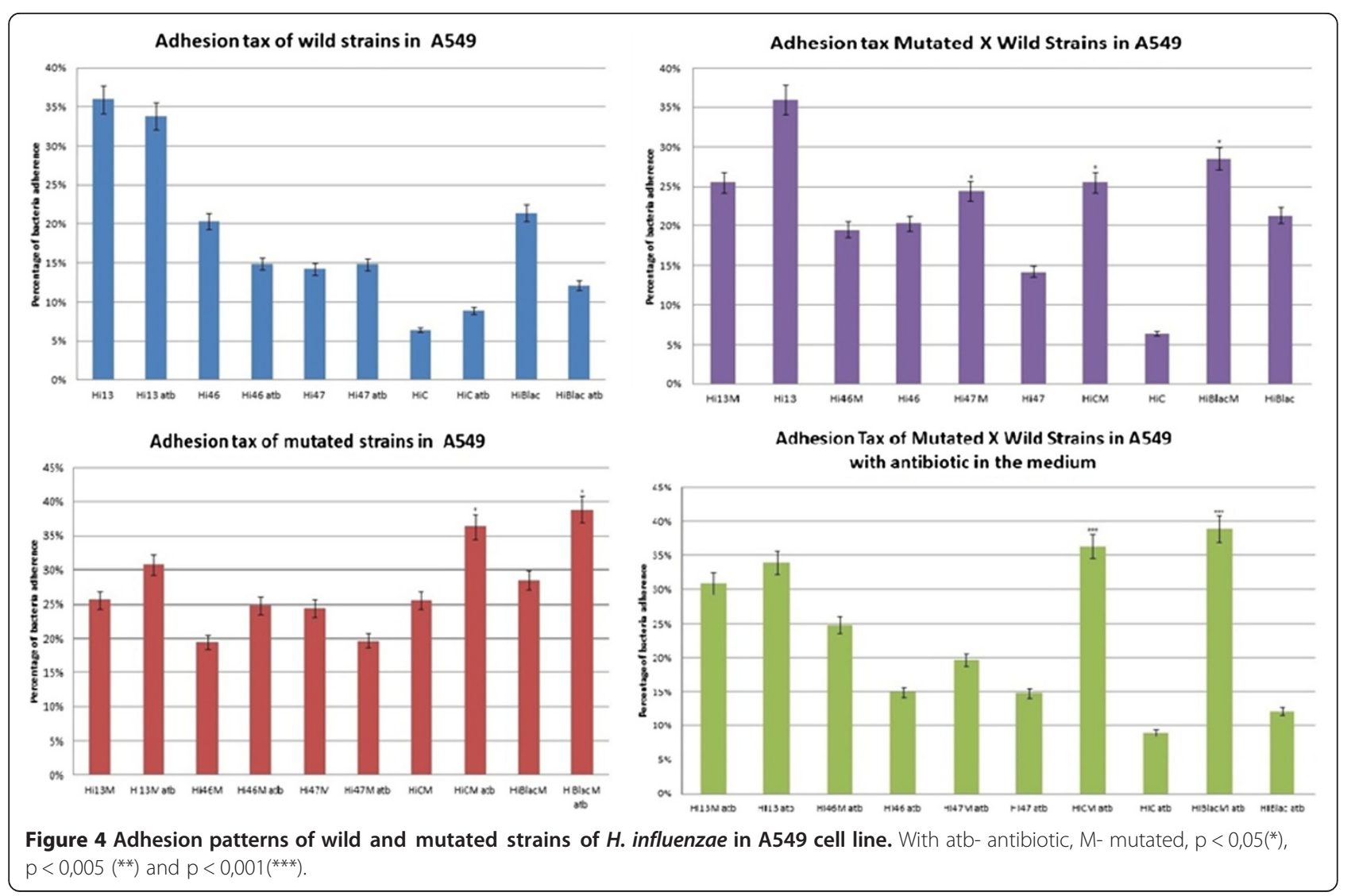




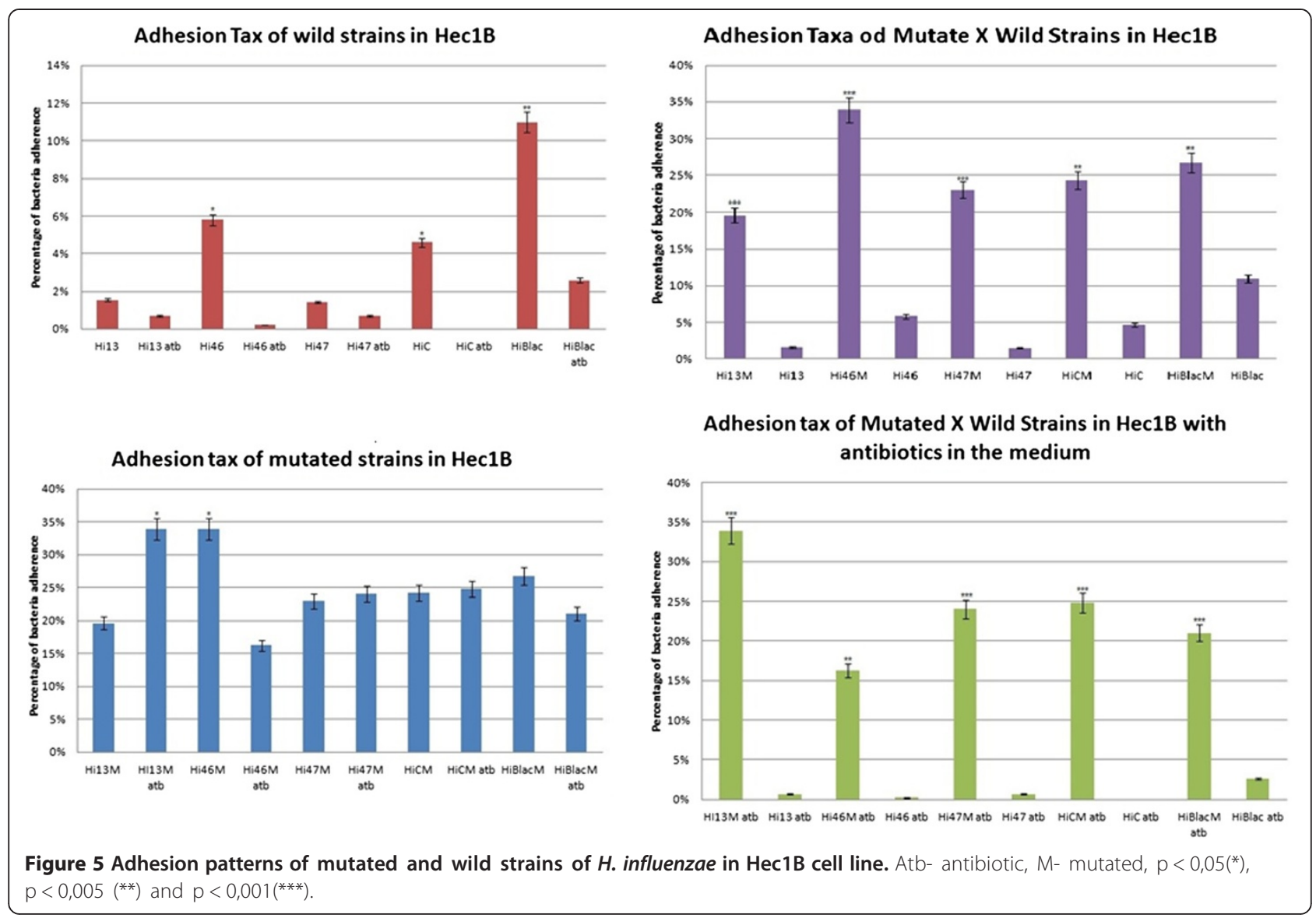

concentration used of chloramphenicol $(2 \mu \mathrm{g} / \mathrm{ml})$, it would not affect the cellular growth of neither A549 nor Hec1B lineages. omp P2 provides $H$. influenzae with resistance to chloramphenicol, thus the presence of this antibiotic in the medium increases the gene expression in mutant strains, at the same time it inhibits the bacterial growth in wild-type strains. Therefore, it was already expected that mutant strains presented a higher adhesion in cell cultures than wild-type ones. Nonetheless, the adhesion taxes without the presence of antibiotics also presented increased results for the majority of mutant strains, with a significant value of $\mathrm{p}<0.05$ for Hi47M, HiCM and HißlacM in A549 cells, while all mutant variants showed highly significant $\rho$ values of $\mathrm{p}<0.01$ and $\mathrm{p}<0.001$ in Hec1B cells.

Bacterial strains presented different adhesion taxes on A549 and Hec1B cells. While all mutant strains showed a major adhesion with and without antibiotics in Hec1B cells, with a significant $\rho$ value when compared to their wild-type, this behavior could not be seen in A549 cells. One possible explanation is the fact that $H$. influenzae is a commensal bacterium of the upper respiratory tract and therefore wild-type strains present a natural capability of adhesion on these cells. On the other hand, these bacteria only have contact with endothelial cells in meningitis cases. As this microenvironment does not permit a direct transition from one host to another, the adhesion on Hec1B does not present any natural evolutionary potential for $H$. influenzae [36,37]. The acquisition of omp P2 gene obtained from $\mathrm{Hi} 07$ strain not only provided a resistance to chloramphenicol, but also increased the adhesion taxes especially in Hec1B cells.

H. influenzae type b P2 porine (341 amino acids, $37.782 \mathrm{Da}$ ) allows the diffusion of small molecules with a molecular weight of until $14000 \mathrm{Da}$ to the periplasmatic space [38]. This is probably the antibiotics way of access into the bacterial cell. Small changes on the amino acid configuration provide different molecule captures by closing the canal, therefore modifying the porine function [39]. The basic amino acid changes in the porine overture loop domains 1 and 3 could difficult the penetration of chloramphenicol to the inner side of $H$. influenzae, resulting into a resistance to this antibiotic and also into a better adhesion to cell cultures.

The adhesion of mutant $H$ influenzae strains on human cells surface is directly linked to the influence of graphene oxide nanoparticles on bacterial transformation, once the resulting mutants presented a higher adhesion to cell lines compared to wild type strains. Some studies have already related atmospheric pollution to cases of bacterial meningitis $[40,41]$. Therefore, this study corroborates to the 
hypothesis that links greater transformation frequency of naturally competent bacteria to the influence of nanoparticles and its consequences to the health of people exposed to them, especially in polluted and arid regions.

\section{Conclusions}

Graphene oxide nanoparticles aid the transformation process, helping to increase the number of CFUs, and the mutants generated with the $\operatorname{omp}_{\mathrm{P} 2}$ gene from a $H$. influenzae resistant strain not only present an chloramphenicol resistance but also have an increased adherence patterns in A549 and Hec1B cell lines. Also, the increase of transformation frequency have some relationships with the adhesion, or the virulence of this bacterium. Then a gene liked to antibiotic resistance acquisition showed a great capacity of not only antibiotic transference characteristics between $H$. influezae strains as the transference of the virulence factors present in different strains in human upper respiratory tract.

\section{Competing interests}

All the authors declare that they have no competing interests in this work.

\section{Authors' contributions}

JNV carried out the Molecular Biology design and plasmids; MCKA carried out the results analysis and revised the manuscript; RFCP carried out the cellular assays tests; LMH carried out the molecular genetics studies; HJC carried out the graphene synthesis and FESEM, HRTEM and Raman tests; VB participated in the drafting of the manuscript and gave technical support in Nanoengineering; ML carried out the molecular genetics studies and also the draft of the manuscript. All the authors read and approved the final manuscript.

\section{Acknowledgements}

Thanks for FAPESP (Grants 2011/14079-2, 2011/21685-6 and 2012/15046-3) and CAPES (fellowship grants for Varela JN) for the financial support for the LABIOTEC.

\section{Author details \\ ${ }^{1}$ LABIOTEC - Biotechnology Laboratory, Department of Biochemistry, Institute of Biology CP6109, University of Campinas - UNICAMP 13083-970, Campinas, São Paulo, Brazil. ${ }^{2}$ NanoEng - NanoEngineering and Diamond Laboratory, School of Electrical and Computer Engineering, Department of Semiconductors, Instruments and Photonics, University of Campinas, UNICAMP, Av. Albert Einstein N.400, CEP 13 083-852 Campinas, São Paulo, Brazil.}

Received: 15 January 2014 Accepted: 4 April 2014

Published: 16 April 2014

\section{References}

1. Wolf J, Daley AJ: Microbiological aspects of bacterial lower respiratory tract illness in children: typical pathogens. Paediatr Respir Rev 2007, 8:204-210. quiz 210-201.

2. Holt JG, Krieg NR, Sneath PHA, Staley JT, Williams ST: Facultatively Anaerobic Gram-negative Rods. In Bergey's Manual of Determinative Bacteriology. 9th edition. Baltimore: Williams \& Wilkins; 1994:175-290.

3. Kroll JS, Langford PR, Loynds BM: Copper-zinc superoxide dismutase of Haemophilus influenzae and H. parainfluenzae. J Bacteriol 1991, 173:7449-7457.

4. Gilsdorf JR, Marrs CF, Foxman B: Haemophilus influenzae: genetic variability and natural selection to identify virulence factors. Infect Immun 2004, 72:2457-2461

5. Rahman M, Hossain S, Baqui AH, Shoma S, Rashid H, Nahar N, Zaman MK, Khatun F: Haemophilus influenzae type-b and non-b-type invasive diseases in urban children ( $<5$ years) of Bangladesh: implications for therapy and vaccination. J Infect 2008, 56:191-196.

6. Bae S, Lee J, Kim E, Lee S, Yu J, Kang Y: Antimicrobial resistance in Haemophilus influenzae respiratory tract isolates in Korea: results of a nationwide acute respiratory infections surveillance. Antimicrob Agents Chemother 2010, 54:65-71.

7. Turk DC: The pathogenicity of Haemophilus influenzae. J Med Microbiol 1984, 18:1-16.

8. Booy R, Heath PT, Slack MP, Begg N, Moxon ER: Vaccine failures after primary immunisation with Haemophilus influenzae type-b conjugate vaccine without booster. Lancet 1997, 349:1197-1202.

9. Wang SR, Tseng MH, Lin WJ, Teng CS, Wang CC: Fatal non-typeable Haemophilus influenzae sepsis complicated with acute respiratory distress syndrome: case report and literature review. Scand J Infect Dis 2005, 37:921-925.

10. Barenkamp SJ, Munson RS Jr, Granoff DM: Subtyping isolates of Haemophilus influenzae type b by outer-membrane protein profiles. J Infect Dis 1981, 143:668-676.

11. Foxwell AR, Kyd JM, Cripps AW: Nontypeable Haemophilus influenzae: pathogenesis and prevention. Microbiol Mol Biol Rev 1998, 62:294-308.

12. Murphy TF, Bartos LC: Purification and analysis with monoclonal antibodies of P2, the major outer membrane protein of nontypable Haemophilus influenzae. Infect Immun 1988, 56:1084-1089.

13. Murphy TF, Bartos LC: Human bactericidal antibody response to outer membrane protein P2 of nontypeable Haemophilus influenzae. Infect Immun 1988, 56:2673-2679.

14. Arbing MA, Hanrahan JW, Coulton JW: Altered channel properties of porins from Haemophilus influenzae: isolates from cystic fibrosis patients. J Membr Biol 2002, 189:131-141.

15. Regelink AG, Dahan D, Moller LV, Coulton JW, Eijk P, Van Ulsen P, Dankert J, Van Alphen L: Variation in the composition and pore function of major outer membrane pore protein P2 of Haemophilus influenzae from cystic fibrosis patients. Antimicrob Agents Chemother 1999, 43:226-232

16. Gazagne L, Delmas C, Bingen E, Dabernat H: Molecular epidemiology of ampicillin-resistant non-beta-lactamase-producing Haemophilus influenzae. J Clin Microbiol 1998, 36:3629-3635.

17. Yamanaka N, Hotomi M, Billal DS: Clinical bacteriology and immunology in acute otitis media in children. J Infect Chemother 2008, 14:180-187.

18. Dimopoulou ID, Kraak WA, Anderson EC, Nichols WW, Slack MP, Crook DW: Molecular epidemiology of unrelated clusters of multiresistant strains of Haemophilus influenzae. J Infect Dis 1992, 165:1069-1075.

19. Dimopoulou ID, Jordens JZ, Legakis NJ, Crook DW: A molecular analysis of Greek and UK Haemophilus influenzae conjugative resistance plasmids. J Antimicrob Chemother 1997, 39:303-307.

20. Leaves NI, Dimopoulou I, Hayes I, Kerridge S, Falla T, Secka O, Adegbola RA Slack MP, Peto TE, Crook DW: Epidemiological studies of large resistance plasmids in Haemophilus. J Antimicrob Chemother 2000, 45:599-604.

21. Cerquetti M, Ciofi degli Atti ML, Cardines R, Giufre M, Romano A, Mastrantonio P: Haemophilus influenzae serotype e meningitis in an infant. Clin Infect Dis 2004, 38:1041.

22. Burns JL, Mendelman PM, Levy J, Stull TL, Smith AL: A permeability barrier as a mechanism of chloramphenicol resistance in Haemophilus influenzae. Antimicrob Agents Chemother 1985, 27:46-54.

23. Takahata S, Ida T, Senju N, Sanbongi Y, Miyata A, Maebashi K, Hoshiko S: Horizontal gene transfer of ftsl, encoding penicillin-binding protein 3, in Haemophilus influenzae. Antimicrob Agents Chemother 2007, 51:1589-1595.

24. Maughan $\mathrm{H}$, Redfield RJ: Tracing the evolution of competence in Haemophilus influenzae. PLoS One 2009, 4:e5854

25. Chen I, Dubnau D: DNA uptake during bacterial transformation. Nat Rev Microbiol 2004, 2:241-249.

26. Maughan $\mathrm{H}$, Redfield RJ: Extensive variation in natural competence in Haemophilus influenzae. Evolution 2009, 63:1852-1866.

27. Zhao QQB A, CHOWDHRY U: Nanotechnology in the Chemical Industry Opportunities and Challenges. J nanoparticles Res 2003, 5:567-572.

28. Rojas-Chapana J, Troszczynska J, Firkowska I, Morsczeck C, Giersig M: Multiwalled carbon nanotubes for plasmid delivery into Escherichia coli cells. Lab Chip 2005, 5:536-539.

29. Mattos IB, Alves DA, Hollanda LM, Ceragiogli HJ, Baranauskas V, Lancellotti M: Effects of multi-walled carbon nanotubes (MWCNT) 
under Neisseria meningitidis transformation process. J Nanobiotechnol 2011, 9:53.

30. Hollanda LM, Cury GC, Pereira RF, Ferreira GA, Sousa A, Sousa EM, Lancellotti M: Effect of mesoporous silica under Neisseria meningitidis transformation process: environmental effects under meningococci transformation. J Nanobiotechnol 2011, 9:28.

31. Borenfreund E, Borrero O: In vitro cytotoxicity assays. Potential alternatives to the Draize ocular allergy test. Cell Biol Toxicol 1984, 1:55-65.

32. Pereira RFC AD, Jacinto RK, Hollanda LM, Verinaud LMC, Machado CML, Lancellotti M: Effects of Neisseria meningitidis Infection in Tumor Glioblastoma Cell Line NG97: Respiratory Pathogen Inducing Apoptosis. J Bacteriol Parasitol 2011, 2:4.

33. Sambrook J, Fritsch EF, Maniatis T: Molecular cloning: a laboratory manual. CSH Laboratory Press; 1989

34. Konowalchuk J, Speirs JI, Stravic S: Vero response to a cytotoxin of Escherichia coli. Infect Immun 1977, 18:775-779.

35. Babich $H$, Puerner JA, Borenfreund $E$ : In vitro cytotoxicity of metals to bluegill (BF-2) cells. Arch Environ Contam Toxicol 1986, 15:31-37.

36. Scaletsky IC, Silva ML, Trabulsi LR: Distinctive patterns of adherence of enteropathogenic Escherichia coli to HeLa cells. Infect Immun 1984, 45:534-536.

37. Kroll JS, Wilks KE, Farrant JL, Langford PR: Natural genetic exchange between Haemophilus and Neisseria: intergeneric transfer of chromosomal genes between major human pathogens. Proc Natl Acad Sci U S A 1998, 95:12381-12385.

38. Ribeiro $\mathrm{H}$, Assunção JV: Efeitos das queimadas na saúde humana. Estud Avançados 2002, 16:24

39. Foster KA, Oster CG, Mayer MM, Avery ML, Audus KL: Characterization of the A549 cell line as a type II pulmonary epithelial cell model for drug metabolism. Exp Cell Res 1998, 243:359-366.

40. Spence JM, Clark VL: Role of ribosomal protein L12 in gonococcal invasion of Hec1B cells. Infect Immun 2000, 68:5002-5010.

41. Benson SA, Occi JL, Sampson BA: Mutations that alter the pore function of the OmpF porin of Escherichia coli K12. J Mol Biol 1988, 203:961-970.

doi:10.1186/1477-3155-12-14

Cite this article as: Varela et al:: Haemophilus influenzae porine ompP2 gene transfer mediated by graphene oxide nanoparticles with effects on transformation process and virulence bacterial capacity. Journal of Nanobiotechnology 2014 12:14.

\section{Submit your next manuscript to BioMed Central and take full advantage of:}

- Convenient online submission

- Thorough peer review

- No space constraints or color figure charges

- Immediate publication on acceptance

- Inclusion in PubMed, CAS, Scopus and Google Scholar

- Research which is freely available for redistribution

Submit your manuscript at www.biomedcentral.com/submit 